\title{
China's impact on the European Union's Arctic policy: critical junctures, crossovers, and geographic shifts
}

\author{
Reinhard Biedermann ${ }^{1}$ D
}

Received: 24 February 2020 / Revised: 8 December 2020 / Accepted: 10 March 2021 /

Published online: 29 May 2021

(c) The Author(s), under exclusive licence to Springer-Verlag GmbH Germany, part of Springer Nature 2021

\begin{abstract}
In 2008, the European Commission perceived the European Union (EU) in an excellent position to collaborate with the five Euro-Arctic states and its strategic partners Canada, Russia, and the USA to shape Arctic governance in the fast-changing environment. However, the Arctic coastal states rejected the EU's multilateral governance approach, while China has emerged as a significant factor in the Arctic. In 2018, China announced the Polar Silk Road to connect East Asia with Europe via Arctic shipping and other connectivity projects. In 2019, the EU started to perceive China as a systemic rival concerning the Belt and Road Initiative. What is the impact of China on the EU's Arctic policies in the Euro-Arctic environment? What are the prospects for collaboration between the EU and China on joint issues? This paper applies process tracing to analyse China's and the EU's Arctic socialization in the early twenty-first century at three critical junctures of Arctic politics. At these junctures, the paper introduces the Arctic situation and the emerging problems, development in agenda setting, the policy processes, and the outcomes of the EU's and China's Arctic approaches. It argues that China's rise as a maritime and Arctic power and its close relations with Russia along the Northern Sea Route shaped the EU's Arctic policies and their shift towards the Barents sub-Arctic region. Implications are more interaction among both there, as China's Polar Silk Road might also challenge the EU's regulatory approach in the Euro-Arctic.
\end{abstract}

\section{Introduction}

As temperatures rise and ice melts, great power and geo-economic conflicts have entered the Arctic region in recent years. In 2012, the European Commission, worried about China's potential mining investments in Greenland, engaged in

Reinhard Biedermann

134230@mail.tku.edu.tw

1 Department of Global Politics and Economics, Tamkang University, No. 180, Linwei Rd., Jiaoxi Township, 26247, Ylan County, Taiwan 
hectic raw materials diplomacy with Nuuk. In the same year, the European Union (EU) and China exchanged views on the Arctic for the first time at the EU-China summit but made no commitments to cooperation on Arctic issues (European Commission 2012b). However, both actors enhanced their Arctic activities and presence in the last decade, and China as an Arctic outsider could successfully portray itself as a 'near-Arctic' stakeholder as the Arctic's dramatic environmental changes also have environmental effects in China (Young 2019).

In 2008, the European Commission perceived the EU in an excellent position to enhance and participate in Arctic multilateral governance (European Commission 2008a, b). However, for multilateral governance to emerge, the EU depends on the Member States' support (Raspotnik and Østhagen 2019: 173). Denmark (via Greenland and the Faroe Islands), Finland and Sweden as EU-Members and Norway and Iceland as parties to the European Economic Area (EEA) Agreement would be important assets for an Arctic EU role. Nevertheless, in contrast to the EU's assumption, the Nordics supported China to achieve a favourable Arctic position, while they sidelined the EU's Arctic governance and regulatory approach. Hence, the main question of this paper: What is the impact of China on the EU's Arctic policies? In answering this central question, this article identifies three critical junctures in Arctic politics and EU-China-Arctic relations and traces China's and the EU's Arctic socialization processes during the successive phases.

The first phase was launched in 2007 when a Russian submarine planted a flag on the Arctic seabed at the North Pole far beyond Russia's recognized exclusive economic zone that attracted both China's and the EU's Arctic attention; the second critical juncture in 2013/2014 was marked by the Arctic Council's acceptance of China as an observer while rejecting the EU's application. That led the EU to revise its Arctic approach, while China has begun to perceive itself as a great polar power. The third critical juncture was China's revealing for the Polar Silk Road (PSR) plans in 2018 and the emergence of China-Russia strategic relations concerning the Belt and Road Initiative (BRI) (Yu and Sui 2020). That contributed to solidifying a joint European Arctic perspective with a shift towards the Barents region. Since 2019, the EU has perceived China as a systemic rival concerning the BRI (EU Commission 2019). Both emphasize multilateral cooperation, but for the EU, multilateralism is about proactive membership in institutions and rules-based governance. For China, by contrast, multilateralism is more a diplomatic approach to working with other countries, intending to balance the USA (Christiansen et al. 2019: 45). However, the systemic rivalry goes further, since it would also challenge the EU's regulatory and rules-based approach. As China and the EU pledged to cooperate on global governance (Wang and Song 2016), the Arctic might become a new arena of political experimentation.

The article argues that these traced developments at regional and global levels led the Euro-Arctic region (the Barents) become a primary strategic sub-Arctic hub for both China and the EU. There, functional pressure might lead to EUChina engagement, particularly concerning infrastructure. For that to realize, the EU and Euro-Arctic have to harmonize their goals, as the critical mechanism for the EU's Arctic socialization is the internalization of norms and interests of the Nordics (Arctic Portal 2020). The Barents is the wealthiest Arctic sub-region. 
However, the globalization and economic development of the Arctic have significant implications for the environment and the populations, the EU and China have to consider.

\section{Critical junctures and geopolitical shifts in the Arctic region}

Long-standing narrations of an 'Arctic distinctiveness' due to the harsh environment, and an 'Arctic exceptionalism' or 'zone of peace' (Young 2019) compared to other regions, are waning. Dodds (2010) foresaw a 'polar Mediterranean'. Tang (2013) compared the Arctic future to a 'New Middle East', under the impression of the global resource price hikes till 2012 and growing external interests in the Arctic's mineral resource riches like rare-earths. Furthermore, in 2019, the US Secretary of State, Mike Pompeo, warned of a new 'South China Sea', criticizing China's and Russia's Arctic militarization (Guardian 2019). These contradictory narrations of the Arctic past and future testify the recently experienced critical junctures in the Arctic. Oran Young (2019), an expert on Arctic governance, expressed that the dramatic environmental changes and the growing presence of external actors contributed to the relative loss of relevance of the Arctic Council, which Young once commended for its achievements on environmental protection. In analytic-methodological terms, the distinction between the independent and dependent variables in the Arctic has become blurred.

This article traces China's and the EU's Arctic socialization processes following three critical junctures and particularly explores China's impact on the EU's Arctic socialization. Process tracing is focused and structured and aims at providing a narrative explanation of a causal path that leads to a specific outcome (Flyvbjerg 2006: 237-241). Process tracing is an empirical application where both agents and structures matter to capture dynamic interactions (Checkel 2014: 114). It means to trace the operation of the causal mechanism(s) at work in a given situation (Checkel 2014: 116). Socialization refers to the process of inducting new actors into the norms, rules, and ways of behaviour of a given community. The endpoint would be internalization, where community norms and rules become taken for granted (Checkel 2014: 117). Process tracing emphasizes 'the identification of a causal mechanism that connects independent and dependent variables' (Vennesson 2008: 232). A mechanism is a set of hypotheses that could be the explanation for some social phenomenon, the explanation being in terms of interactions between individuals and other individuals, or between individuals and some social aggregate (Hedström 2008: 25, 32-33).

This paper assumes that critical junctures at the regional Arctic level, as well as the global level, interact in ways that transform the Arctic as becoming a part of an emerging Eurasia. Calder (2019) described a critical juncture as a critical change period, which provides micro-level insight into timing, sequence, and causality through which political-economic systems and their institutions change in the way they do. Calder defined crossovers as broad periods of transition in structural terms that provide macro-level insights into the nature of the systemic transition. The article sheds light on episodes of emerging rivalries and cooperation 
between China and the EU and the Euro-Arctic in these transitional periods, which also might lead to more cooperation in the future. Four questions structure the critical junctures and phases concerning China and the EU in the Arctic.

- Situation and emerging issues: What are China and EU perspectives?

- Agenda setting: What values/norms and interests guide the responses to the new situation?

- Processes: How do China and the EU pursue their policies?

- Policy effectiveness: What are the outcomes?

During and after these junctures, the political dynamics moved from the central Arctic during the first critical juncture, towards the Northern Russian coast after the second critical juncture, and towards the Euro-Arctic Barents region (Map 1) (Biedermann 2019) where the central focus of politico-economic activity is now for the years to come, at least between the EU and China. However, these geopolitical shifts, which are a consequence of the impact China has on the Arctic and the EU's Arctic policies, strengthened the EU's presence in the Barents, as the bloc is better institutionalized there than elsewhere in the Arctic. China and the EU encounter at the Barents region due to functional pressure, as China's proclaimed Polar Silk Road interests also need support by the Nordics and the EU, who have their infrastructural programs in mind.

\section{Critical junctures, crossovers, and geographic shifts}

\section{Critical juncture 2007/2008}

\section{Situation and emerging issues}

Arctic coastal states have dealt with sovereignty issues with familiar routine (Blunden 2012; Wegge 2011): They proposed extensions of their continental shelves and submitted their proposals to the United Nations Convention of the Law of the Seas (UNCLOS) Commission on the Limits of the Continental Shelf. However, when in 2007 two Russian mini-submarines planted the National flag on the bottom at the North Pole at a depth of $4300 \mathrm{~m}$, the Arctic gained worldwide media attention. The delineating of the extended continental shelf in the Arctic Ocean still might take many years to settle. Will the Arctic remain a 'zone of peace'?

In Mai 2008 on the invitation of Denmark, the five Arctic littoral states Canada, Denmark (via Greenland), Norway, Russia, and the USA (via Alaska) acted pragmatically and agreed on the Ilulissat Declaration (Arctic Ocean Conference 2008). It stated that UNCLOS is the legal foundation for sovereign rights in the Arctic Ocean. Furthermore, it proclaimed strengthening practical cooperation concerning the safety of navigation, disaster response, search and rescue, environmental monitoring, and scientific cooperation. The Declaration also emphasized that the Arctic Council, which includes the mentioned Nations plus Sweden, Finland, and Iceland, has already taken decisive steps on these issues and that there was "no need 
to develop a new comprehensive international legal regime to govern the Arctic Ocean.' Kobza (2015) summarized that the Arctic system as having many traits of a 'concert of powers', based on the interests of several strong state actors and built on a light international structure using traditional instruments of intergovernmental relations.

The flag incident sharpened China's geopolitical perspective on the Arctic (Tonami 2016). While China rejected its status as 'Arctic outsider' (Jakobsen and Peng 2012), Beijing's jurisdictional rights indeed are that of an outsider (Gayazova 2013). In the high seas and under UNCLOS, China has rights of scientific research, navigation, overflight, fishing, and the laying of submarine cables and pipelines as well as to resource exploitation in the area.

In 2010, a boat collision incident in the East China Sea west of Okinawa islands close to the Senkaku islands, which China claims, affected the EU's Arctic policies in the aftermath. As emotions heated up, China enacted an export boycott of rareearths, which are in high demand for modern high-tech products in Japan, but also elsewhere. China, the source of most of the world's rare-earths, has tried to maintain that monopolistic position by foreign acquisitions. The German industries were strongly concerned about whether China would use its monopoly to enforce technology transfers to China. That led the EU to look for new suppliers in its Northern neighbourhood (European Commission 2008b, 2011). The Commission issued a list of critical raw materials, with Greenland having good potential for many of them.

\section{Agenda setting}

Ever since China sent its first official Arctic expedition in 1999 (Tonami 2016, Alexeeva, Lasserre 2012), its standard primary Arctic interest was scientific research, followed by resources and fishing (Jakobson 2010). China also adopted a low-profile political style by avoiding confrontation from influential littoral states. The avoidance of sensitive issues such as resource exploration 'will allow China to participate in global cooperation constructively' (Jakobsen and Peng 2012, p. vi). In Ny Alesund on Svalbard, China established its first Arctic Research Center. Major research institutions from all Nordics became a partner. Between 1999 and 2017, China made nine Arctic research expeditions and became a leader in Arctic research, also providing nautical maps for free use.

China also has the interest to enhance its legal position in the Arctic. Rainwater (2013) wrote that the Chinese state media language of 'common heritage of mankind' shall expand China's Arctic legal rights and would form a sort of 'lawfare' to circumvent its weak status as a non-Arctic state. Also, Brady (2017: 195) observed that Chinese state media often use the phrase 'the North Pole belongs to all humanity' to internationalize Arctic issues.

The EU perceived itself in a formidable position to become an eminent actor in the Arctic, since the 'EU policies on the environment, climate, energy, research, transport, hunting and fishing all have a direct bearing on the Arctic region' (European Commission 2008a, b). In October 2008, the European Parliament (EP) passed a Resolution that proposed an Arctic Treaty, inspired by the Antarctic Treaty. The 


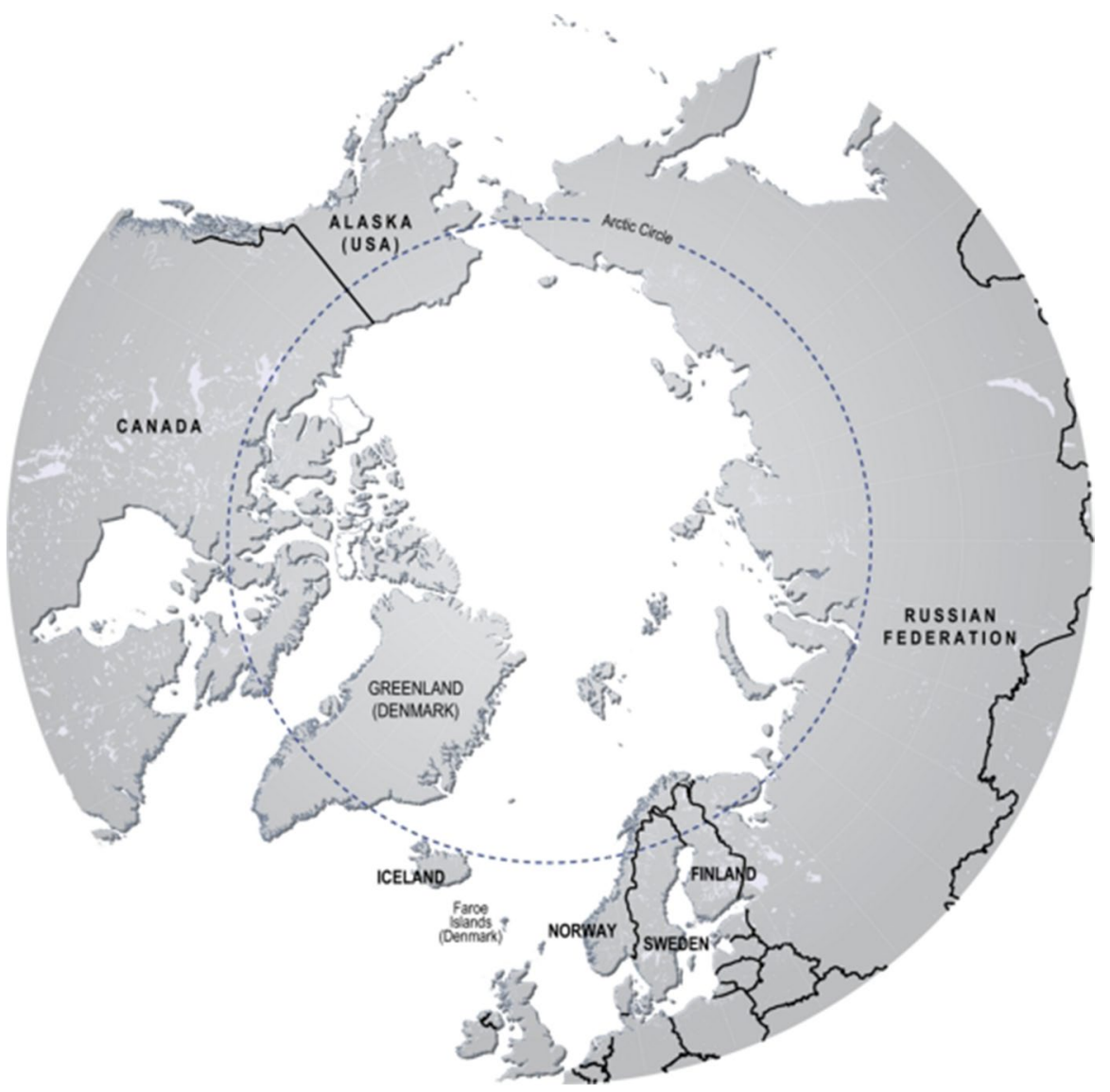

Map 1 Arctic political map, by Hugo Ahlenius (Cartographer), https://www.grida.no/resources/7845

resolution called the European Commission to "promote the opening of international negotiations leading to adopting an international treaty for the protection of the Arctic'. In November 2008, the Commission issued its first Arctic policy paper. Instead of a treaty, it advocated 'enhanced Arctic multilateral governance' (2008a; b: 3). Also, the European Council expressed support for 'reinforced multilateral governance' (Council of the European Union 2009: 1). The Commission perceived itself as being in a strong Arctic position, since.

[T] he European Union is inextricably linked to the Arctic region (...) by a unique combination of history, geography, economy and scientific achievements. Three Member States (...) have territories in the Arctic. (...) Iceland and Norway - are members of the European Economic Area. Canada, Russia and the United States are strategic partners of the EU. European Arctic 
areas are a priority in the Northern Dimension policy. (European Commission 2008a, b:1).

The EU prioritized cooperation, environmental protection, and sustainable economic development. The quoted Northern Dimension (ND) includes the EU, Iceland, Norway, and Russia and shall promote stability, prosperity, and sustainable development. The Commission committed to developing land and air transport infrastructures in the populated European Arctic areas and suggested the establishment of an ND Partnership on Transport and Logistics.

The Commission announced, 'to defend the principle of freedom of navigation and the right of innocent passage in the newly opened routes and areas'. Besides, the Commission favoured a multilateral governance approach concerning 'the fragmentation of the legal framework, the lack of effective instruments, the absence of an overall policy-setting process and gaps in participation, implementation and geographic scope'. That could stand in conflict with the Ilulissat Declaration. Besides, the EU announced to consider unilateral regulations on environmental issues. That includes the banning and the placing on the market, import, transit, and export of seal products. In 2008, the EU decided to approve a ban on trade in commercial seal products.

The EU's new raw materials diplomacy set an eye on the Arctic. In its 2012 Arctic communication, the EU commits to 'actively access to raw materials notably through strategic partnerships and policy dialogues' (European Commission 2012a, p.10). The EU accused China of being a problem for access to many raw materials (European Commission 2012c, p.19).

\section{Processes}

The EU's main institutional Arctic goal was to become an observer of the Arctic Council. However, Norway, Iceland, and Denmark criticized the EU's Arctic policy program. The Nordics issued their first Arctic strategies around 2010 (Norway 2006, Iceland 2009, Finland 2010, Sweden 2011; Kingdom of Denmark 2010) ${ }^{1}$ and have regularly revised them since then. Together with Norway, Canada initiated dispute settlement procedures within the World Trade Organization against the EU's ban on seal imports. Denmark expressed that the EU neglects 'the laws, traditions, cultures and needs of Arctic societies' (Kingdom of Denmark 2010: 52). This ban led Canada to reject the EU as an Arctic Council observer. Furthermore, the EU led an international coalition against Iceland to stop whaling. That further deteriorated the EU-Iceland relations, and Iceland refrained from becoming an EU member.

By contrast, Sweden and Finland strongly identify with the EU goals. Sweden committed to contributing to the development of an EU Arctic policy actively and - extraordinarily — 'fully agrees' with the EU's goal of an enhanced Arctic

\footnotetext{
1 Nordregio (2017), Nordregio Policy Brief 1, https://archive.nordregio.se/Global/Publications/Publi cations\%202017/PB\%202017\%201.pdf (accessed October 20 2020).
} 
multilateral governance (Sweden 2011: 19). Also, Finland strongly supported the EU in the Arctic: 'Finland's Strategy for the Arctic Region' (2010) expressed that '[t]he European Union's Arctic policy is part of both the Union's internal policies and its external relations'. ${ }^{2}$ Finland committed to working together with Sweden and Denmark to clarify the EU's role in the Arctic and to consolidate the EU's Arctic policy, including the observer application (Finland 2013).

The EU's regulatory approach on shipping, resource exploration, and related environmental issues met criticisms in the EEA: Both Iceland and Norway disapproved the June 2013 Directive on Safety of Offshore Oil and Gas Operations, following the Deepwater Horizon incident in the Gulf of Mexico in April 2010 (2013/30/EU) (European Commission 2012a, p.9). That set of rules should help to prevent and respond swiftly to occurring accidents (European Maritime Safety Agency 2019). Norway rejected this directive as unnecessary, but as an EEA member, it has to comply with most of the single market rules without having any influence in drafting.

To give life to the raw materials diplomacy, the EU started a dialogue with Greenland on raw materials in 2011. In June 2012, the Commission Vice President and Commissioner for Industry and Entrepreneurship, Antonio Tajani, visited Greenland and offered development aid if Greenland would not give China exclusive access to its rare-earths metals. The Commission signed an agreement in Greenland's Nuuk to ensure that the island's minerals remained available to free markets. That obscure EU manoeuvre happened in context with China's President Hu Jintao's visit to Denmark that took place in the same month, which was the first in 62 years of history of their diplomatic relations. Media like Reuters (2012) speculated that 'Greenland's huge mineral wealth may have been the elephant in the room'. That was the first indirect duel between the EU and China in the Arctic, which remained an episode. As of March 2020, out of 39 mining licences approved by the Mineral Licence and Safety Authority of the government of Greenland, companies from the United Kingdom held 14, from Greenland six, from Denmark and Canada each four, with the others distributed to mining companies to Czech Republic, Ireland, South Africa, and Australia. China holds none. ${ }^{3}$

China conducted an un-precedent summit diplomacy towards all Euro-Arctic states. Hellstroem (2014) expressed that the Nordics are easy to deal with from China's perspective. Already in 2002, then-President Jiang Zemin made the first visit by a head of state to Iceland, which then was the entry point to reaching the Nordics (Tonami 2016). Since 2008, Denmark has become a key European player for China through the 'comprehensive strategic partnership'. Furthermore, in 2013, China and Finland upgraded their bilateral relationship to a 'future-oriented partnership'. Till 2013, on the other hand, China and Norway had no high-level official exchanges, and China decreased cooperation with Norway. Oslo had the interest to get relations

\footnotetext{
${ }^{2}$ The Arctic strategies of Arctic countries for download: https://arcticportal.org/arctic-governance/arctic-policies-database (accessed February 17 2020).

3 Information provided on request by the author from the Mineral Licence and Safety Authority of Greenland.
} 
back to normal, while Beijing wanted to become an observer of the AC in 2013 . That contributed to normalizing the relations.

\section{Outcomes}

Along the Ilulissat Declaration, the AC modified conditions for becoming an observer. Applicants have to 'recognize Arctic states' sovereignty, sovereign rights, and jurisdiction in the Arctic'. ${ }^{4}$ Furthermore, observers have to respect the values, interests, culture, and traditions of Arctic indigenous peoples. They should work with member states and permanent participants to bring Arctic concerns to global decision-making bodies. Observers are invited to the Council meetings and encouraged to make 'relevant contributions' at the level of Working Groups. An observer may propose projects and submit written statements at Ministerial Meetings.

In 2013 at the Kiruna Ministerial Meeting, the Council accepted states from Asia for the first time since its foundation in 1996, namely China, Japan, South Korea, India, and Singapore (Lunde et al. 2016). Also, the USA, Canada, and Russia finally accepted China's application. That marks a trend towards globalization of the Arctic. However, the EU was left out in the cold, and the new above-mentioned conditions for observer explain why. Tang (2013) finds that the EU's failed application would stem from AC Members misgivings of the EU's 'multilateral governance' of the Arctic. Already in 2012, the EU stopped using 'multilateral governance' in Arctic policy papers (Tang 2013). However, the EU may observe Council proceedings '[u]ntil such time as Ministers of the Arctic States may reach a final decision'. In the 2014 EU's Council conclusions (Council of the European Union 2014), the Council only reiterated its position of the importance of respecting international law principles, including the freedom of navigation and the right of innocent passage.

China's conclusion of a Free Trade Agreement (FTA) with Iceland in April 2013 after intensive Chinese diplomatic outreach was the first of its kind between China and a European country. Trans-Arctic shipping, resources development, scientific research, et cetera are also part of the agreed cooperation. Iceland makes more than $50 \%$ of its trade with the EU and only $5 \%$ with China, signifying immense potential. ${ }^{5}$ The EU could have increased its Arctic profile tremendously with Iceland. However, neither became the EU Arctic Council observer, nor did Iceland become an EU member. Instead, Iceland played the Chinese card, as did the other EuroArctic states, which fully welcomed China's Arctic rise in this honeymoon phase. The observer status led China's new President Xi Jinping to characterize China as a 'polar great power' (Sorensen 2018, p. 3). The EU, partly self-inflicted, remained a marginal and heterogeneous Arctic actor.

\footnotetext{
${ }^{4}$ Observers of the Arctic Council, see https://arctic-council.org/en/ (accessed November 252020$)$.

5 The European Commission, Trade Policy, Countries and Regions, Iceland, May 19 2020, https://ec. europa.eu/trade/policy/countries-and-regions/countries/iceland/ (accessed July 12 2020).
} 


\section{Critical juncture in 2013/2014}

\section{Situation and emerging issues}

Coincidental developments led China's primary focus from the central-Arctic shift to the Russian Siberian coast and the Euro-Arctic Barents region. Most notably, in 2013, Xi announced the One Belt One Road (now Belt and Road Initiative, BRI) in Astana in Kazakhstan. Later in the same year, Xi announced the concurrent $21^{\text {st }}$ Maritime Silk Road (MSR) in Jakarta in a speech to the Indonesian parliament. The MSR with its 'blue economic passage' has the goal to develop the maritime economy, shipping lines, ports, and harbours, mostly in the Asian environment towards Eastern parts of Africa. The Northern Sea Route (NSR) did not play a role yet back then. However, in the same year, the MV Yong Sheng was the first commercial vessel to reach Rotterdam using the NSR. Shipping became now central in China's Arctic interests (Huang et al. 2014, Lasserre, Alexeeva 2014). Hence, the BRI/MSR also streamlined China's Arctic policies, which turned towards Russia along the Siberian coast concerning resource infrastructures, automatically enhancing shipping activities and experiences. The NSR has the most significant potential for traversing the Arctic on a regular base. It is also the shortest route available; at 4000 miles, it is approximately $40 \%$ shorter than the overstrained Suez Canal and the Southern route, which means roughly 20 days. In 2015, COSCO announced the launch of regular Arctic shipping to Europe and established itself as the leading trans-Arctic shipping company (Tonami 2016). In 2017, at least six Chinese flagged commercial vessels made use of the shortcut to Europe. Still, this route is only passable during the summer months. The same year, China identified Arctic shipping lines as part of the 'blue economic passages'.

The other, external, development was Russia's annexation of Ukraine's Crimea in 2014 that led to Western US-led economic and financial sanctions policy against Russian actors. Calder, in his book Super Continent: The Logic of Eurasian Integration (2019) argued that Russia became dependent on China and its investments related to China's BRI. The Ukrainian crisis made the Russian Arctic a new frontier for Moscow's economic diplomacy with China. Russia refurbished military bases along the coast. China's energy and shipping interests are symmetric with Russia's Arctic economic interests due to the self-inflicted problems Russia has with the West. For the Euro-Arctic, the China-Russian alliance also meant the beginning of an incremental reassessment of China's Arctic presence, amidst Russia's growing assertiveness and military manoeuvring in the Barents and the Baltics. The Kola Peninsula in the Barents is home to Russia's Northern Fleet and a large part of the Russian nuclear arsenal. Great power rivalries and rapidly growing military tensions in the Arctic, particularly in the Barents region, returned. ${ }^{6}$ NATO in October 2018 conducted the largest manoeuvre ('Trident Juncture') since the 1980s in central and

\footnotetext{
${ }^{6}$ The Barents Observer, Levon Sevunts, September 16 2020, Experts warn of a potentially 'deadly' great power games in the Arctic, https://thebarentsobserver.com/en/security/2020/09/experts-warn-poten tially-deadly-great-power-games-arctic (accessed November 262020 ).
} 
eastern Norway and in parts of Sweden and Finland to practice against an unnamed invasion under Article 5 collective defence scenario. Norway, Iceland, and Denmark participated as NATO members, while Sweden and Finland were also engaged.

For mentioned reasons, including Iceland's and Denmark's critical positions, also the EU shifted its attention to mechanisms in the Barents. Economically, the EU 'rediscovered' the Barents region, since the Euro-Arctic 'has significant potential to support growth in the rest of Europe' (European Commission 2016: 9).

\section{Agenda setting}

In 2014 and in line with the BRI, China asked for dialogue and communication under the framework of the China-EU Maritime Transport Agreement and for strengthening coordination and cooperation within the International Maritime Organization (IMO) (FMPRC 2014). In contrast to the logic of resource competition, which inhibits a zero-sum game naturally, transport and infrastructure might inhibit a positive-sum situation between European and Chinese interests. The EU affirmed to engage with Asian states on issues of shared concern in the Arctic and grouped China with India, Japan, Korea, and Singapore as countries 'beyond the Arctic' (European Commission 2016: 15). Amidst the rising geopolitical meaning of the Arctic, the EU declared to engage in a 'strategic dialogue with Arctic stakeholders and third countries on security matters [...]' (European Commission 2016: 14; European Commission 2017).

In October 2015, on the occasion of the $3^{\text {rd }}$ Arctic Circle Assembly in Reykjavik of Iceland, authoritative speeches clarified China's Arctic goals for the first time. China's Vice Foreign Minister Zhang Ming gave a keynote speech. He demanded respecting the rights of non-Arctic countries and the interests of the international community, building a multi-level framework of Arctic cooperation with win-win results. ${ }^{7}$ Foreign Minister Wang Yi 1 day later expressed that 'China is an important stakeholder in the Arctic', that '[t]he future development of the Arctic bears on the common destiny of mankind', and that 'China believes that the rights of non-Arctic countries under international law in the Arctic and the collective interests of the international community should be respected. ${ }^{8}$

The EU in its new Arctic paper 'An integrated European Union policy for the Arctic' outlined three priority areas: climate change and safeguarding the Arctic environment; endorsing sustainable development in the region; and advocating international cooperation on Arctic issues (European Commission 2016: 17; Council of the European Union 2016). Still, the EU perceived competition on resources as a potential for tensions in the region (European Commission 2016: 4). The EU pledged to continue to support regional and sub-regional cooperation, including through its membership of the BEAC and the ND policy (European Commission

\footnotetext{
7 https://www.fmprc.gov.cn/mfa_eng/wjb_663304/zzjg_663340/xos_664404/gjlb_664408/3306_ 664580/3308_664584/t1307440.shtml

${ }^{8}$ https://www.fmprc.gov.cn/mfa_eng/wjb_663304/zzjg_663340/xos_664404/gjlb_664408/3306_ 664580/3308_664584/t1307451.shtml
} 
2016: 14). Transport and infrastructure as a base for economic development in the Euro-Arctic are central. Finland and Sweden, in contrast to Denmark, are significant supporters of an EU Arctic strategy and essential for a coordinated EU Arctic policy (Stępień and Koivurova 2017). Sweden, in its 2014 Arctic strategy, emphasized the utilization of the Barents Cooperation and the EU's various cooperation programs and funds. Also, Stockholm reiterated to actively promote the EU in the High North and the application for an observer in the AC (Sweden 2014). While the EU's marine offshore policies and regulatory style provoked Oslo's scepticism, Norway appreciates the EU's onshore potentials for cooperation under the Barents EuroArctic Transport Area and committed to taking an active part (Norway 2017: 33).

\section{Processes and outcomes}

The BRI entered centre stage in China's Arctic campaign. All Nordics became founding members of the BRI-accompanying Asian Infrastructure Investment Bank (AIIB) in 2015/2016. China invited the Nordics to the first and second International BRI Forum in Beijing in 2017 and 2019. However, in 2017, only the Minister of Transport and Communications of Finland participated. Hence, the Nordics displayed a wait-and-see perspective concerning the BRI, with the exemption of Helsinki, which in that phase shows special interests in China's Arctic campaign. In 2017, Finland's Prime Minister Juha Sipilä declared on a state visit in Beijing an expansion of their Arctic cooperation under the BRI framework and calling for the Arctic cooperation of Northern European countries with China. Furthermore, negotiations of a 10,500 km cable through the Arctic have taken place in Finland to provide a faster data connection between Europe and China.

The Russian-Chinese BRI cooperation in the Arctic moved into the limelight. In 2017, President Xi and Russia's Prime Minister Dmitry Medvedev agreed to jointly develop the Polar Silk Road and expand the use of the NSR. The ChinaRussia Yamal liquid natural gas project between China National Petroleum Corporation, Russia's Novatek, and French Total planned an estimated annual output of 16.5 million tons by 2019. Chinese investments are indispensable for Russia to unearth the Arctic's economic potentials. The Russian Arctic might double Russia's global share in that market. That Russian-majority project worth US\$27 has outshined all China-Euro-Arctic projects by far.

Also, China's Arctic strategy has become more security-related, backed up by the military (Havnes 2019). In 2015, five Chinese warships were navigating along the Alaskan coast that led observers to conclude that China protracted its marine scope into the Arctic (Brady 2017). Sweden and Norway, but even Denmark, started to perceive China as a potential threat in the Arctic. However, Havnes did not find evidence of a Chinese military alignment with Russia. In Greenland, China sought to build airports and naval facilities (Politico, May 6, 2019). China stepped back from that efforts after criticisms from the USA. If a strategic Arctic triangle including the USA, China, and Russia is to emerge, what does that mean for the EU and internal Arctic coherence?

The 2017 appointment of an EU Ambassador at Large for the Arctic, MariaAnne Coninsx demonstrates the enhanced significance the EU detaches to the High 
North. Coninsx portrayed the EU as being in the Arctic (Coninsx 2019), contrasting China's 'near-Arctic' theory. Raspotnik and Østhagen (2019) observed that the EU had developed a geopolitical sense about its Northern neighbourhood. Also Riddervold and Cross (2019) observed that Russia's Arctic military manoeuvres close to the Nordics led the EU's interest in the Arctic to sharply increase and the EU to mobilize a 'reactive power' in the Far North. Threat perceptions brought the Nordics closer to the EU.

The EU's Arctic policy reached a more tangible shape after 2013 (Pérez and Yaneva 2016). Geopolitically, the EU's Arctic policy shifted to the Barents, where it is institutionally more robust settled and where Denmark and Iceland play a minor role. Economically, the Barents is the most promising Arctic sub-region: Sweden and Finland are rich in mineral resources, including rare-earths, and the Barents is rich in proteins, and also for decades to come the most promising route for transArctic shipping as part of the NSR, as new research suggests (Eliasson et al. 2017).

\section{Critical Juncture 2018/2019}

\section{Situation and emerging issues}

In 2018, 10 years after the initial Declaration of Ilulissat, Denmark invited the other Arctic littoral states again to renew the Declaration and to confirm the $2008 \mathrm{Dec}-$ laration at times when geopolitics returned to the Arctic. However, in 2019, at the biennial ministerial meeting of the Arctic Council held in Finland's Rovaniemi, the US secretary of State Mike Pompeo dubbed the Arctic as 'an arena of global power and competition'. He also warned that the Arctic Ocean could 'transform into the new South China Sea, fraught with militarization and competing territorial claims'. The USA rejected China's claim as being 'near-Arctic'. Besides, for the first time of this meeting, the foreign minister could not agree on a joint final declaration. In August 2019, US President Donald Trump suggested the USA buy Greenland, the world's third-largest island, for strategic and geopolitical reasons. Denmark outright rejected that proposal and emphasized the sovereignty of the people of Greenland. Besides, Denmark also expressed concerns about China's interests in Greenland for the first time. For instance, the Danish Defence Intelligence Service expressed that China's military is increasingly using scientific research in the Arctic as a way into the region and that China has a 'dual-purpose', warning of intensifying geopolitical rivalry in the High North (Reuters 2019). Greenland, but also Iceland, moved to the centre of US-China geopolitical struggles in the Arctic, while the EU absented itself.

However, also China's Arctic interests have shifted to the NSR and the Barents Sea, given that $80 \%$ of trans-arctic shipping goes through Norwegian waters. Between 2013 and 2019, shipping in the Arctic Polar Code area increased by 25\%

\footnotetext{
9 The Arctic Institute, October 22 2020, The Return of Great Power Competition to the Arctic, https:// www.thearcticinstitute.org/return-great-power-competition-arctic/ (accessed December 72020 ).
} 
from 1298 vessels to $1628 ; 625$ or $41 \%$ of these vessels were fishing vessels, 155 vessels were general cargo ships, and 86 were bulk carriers. The total distance sailed by all vessels increased by $75 \%$ in the Arctic Polar Code area from 2013 till 2019 (PAME 2020). In 2019, there were 37 transits from Pacific-Asia to Europe, such as the COSCO ship Tian You, which sailed from Shanghai on August 26 to arrive in Hamburg on September 20. Of 27 ships that transited the NSR in 2018, 8 were from $\operatorname{COSCO}\left(2017: 27 / 5 ;\right.$ 2016: 19/2) (Humpert 2019). ${ }^{10}$

2019, the Commission sees China not only as a 'cooperation partner with whom the EU has closely aligned objective' but also as a 'systemic rival promoting alternative models of governance' (European Commission 2019: 1). The EU criticizes China's BRI conduct, based on in-transparent deals, instead of a rules-based regulatory approach. Calder (2019) termed this rivalry as 'distributive globalism' vs (the EU's) regulatory globalism. It is the in-transparency about finance, assumed environmental unsustainability, and opaque decision-making and conditions the EU criticizes. The EU's new domestic investment regulation (EU) 2019/452 is an expression of this new rivalry. That is an adoption of an FDI screening mechanism, which in practice must be set up by the EU Member states. Of the Euro-Arctic states, Denmark and Finland implemented such a mechanism.

Besides, the European Commission's in-house think tank suggested that the EU should 'exercise caution' in its Arctic engagement with China, 'as China's long-term aspirations remain unknown' (EPSC Strategic Notes 2019:13). The Commission expressed that China's naval claims in the South China Sea and the refusal to accept binding arbitration rulings would 'stand in contrast to China's demands for representation on Arctic issues' (European Commission 2019: 4).

The 'Arctic exceptionalism' or 'distinctiveness' seems to come to an end. Oran Young (2019), a long-standing critic of ideas for an Arctic Treaty, asked for a reset in Arctic governance and argued that an Arctic Treaty, analogue to the Antarctic Treaty of 1959, could be a better way to govern the emerging Arctic issues. The loose governance structure with the Arctic Council and various other governance mechanisms could not manage any more the rapid environmental changes and the rise of influential external stakeholders like China and the EU in that region.

\section{Agenda setting}

In January 2018, the State Council published 'China's Arctic Policy'. It announced the plan of a 'Polar Silk Road' (PSR) as part of the BRI: '[t]he Arctic is gaining global significance for its rising strategic, economic values and those relating to scientific research, environmental protection, sea passages, and natural resources. [...]. It is an issue with global implications and international impacts' (Foreign Ministry of the People's Republic of China (FMPRC) 2018: 1). China made explicit commitments to global, regional, multilateral, and bilateral mechanisms for a wellorganized 'Arctic Governance System' (Foreign Ministry of the People's Republic

\footnotetext{
${ }^{10}$ Information collected from Nord University Information Office, https://arctic-lio.com/ (accessed 8 December 2020).
} 
of China (FMPRC) 2018: 4). That comes close to the EU's 'multilateral governance' proposal a few years earlier. China 'shoulders the important mission of jointly promoting peace and security in the Arctic' (Foreign Ministry of the People's Republic of China (FMPRC) 2018: 3). It perceives itself as a 'near-Arctic state'. Beijing also wants to take part in developing new rules and safeguard 'the common interests of all nations and the international community' (Foreign Ministry of the People's Republic of China (FMPRC) 2018).

The EU's institutional strength in the Arctic remained limited to the Barents. The EU is a member of the BEAC, founded in Kirkenes in Northern Norway in 1993; the Council of the Baltic Sea States (founded in 1992) where the EU has a special status; and the ND (founded in 1999, renewed in 2006). BEAC also discusses infrastructure issues. The ND is the main forum for cooperation and coordination between the EU and Russia on matters in the Barents Sea and shipping routes. The ND includes different policies and partnerships, notably in Transport and Logistics. The EU also plans an active role in the Barents-Euro-Arctic Transport. For a while, the EU members discuss railway and tunnel projects in the Baltic region better to connect the Baltic coastal states with the European continent. Discussions about a bold tunnel project to connect Helsinki with Estonia's Tallinn under the Baltic Sea are two decades old (Barents Observer 2019). Has China's political will and financial prowess the potential to skip the scales? The EU's Commission paper 'EUChina - A Strategic Outlook' of 2019 outlined cooperation on infrastructure, which is of relevance for the EU's and China's infrastructure interests in the Arctic as well:

The EU-China Connectivity Platform represents an initial opportunity to strengthen cooperation and work in common and transparent ways and should be expanded. It aims at promoting sustainable transport corridors based on the principles of the Trans-European Transport networks policy. The imminent launch of a study on railway corridors, between the EU and China, exemplifies the possibility of creating synergies with the Trans-European Transport network policy.

Furthermore, with the infrastructural plans for the Barents Arctic subregion, China, the EU, and the Nordics for the first time might have a vision for cooperation on Arctic matters. For the EU and the Nordics, cooperation with China implies environmental severe and sustainability challenges and, last but not least, the inclusion of the indigenous and local populations.

\section{Processes and preliminary outcomes}

In 2019 at the $21^{\text {st }}$ EU-China summit in Brussels, the joint statement included a section with relevance for cooperation in the Euro-Arctic region. Concerning the BRI, the China-EU summit joint statement expressed that.

[t]he two sides will continue to forge synergies between China's Belt and Road Initiative and the EU Strategy on Connecting Europe and Asia as well as the EU Trans-European Transport Networks ... in the framework of the China-EU Connectivity Platform, ... on sustainable Railway-based Corridors between 
China and Europe. The two sides will enhance communication within the framework of the EU-China Connectivity Platform. ${ }^{11}$

Also in April 2019, at the second BRI Forum for International Cooperation in Beijing, and within the Maritime Silk Road Port Cooperation Mechanism, thirteen countries participated. Among them were eight European countries, but only one Nordic, namely Denmark (Belt and Road News 2019). At that BRI Forum, the National Development and Reform Commission of China made public a Joint Statement on the Study of China-EU Railway-based Integrated Transport Channels with the European Commission. Within the framework of the ND and in 2019, Railway companies from Latvia, Finland, Poland, Russia, and Lithuania shared their opinions and their potential contributions on the development of the new routes towards Asia. The General Director of China Harbour Engineering Company expressed China's view (Northern Dimension 2019). That was the first time discussions for joint projects with relevance for Euro-Arctic development took place, in line with the 2019 EU-China summit joint statement.

Beijing assumes synergy between the extended Trans-European Network for Transport with BRI and Eurasian connectivity and promotes BRI cooperation with Norway, intending to promote connectivity on the Eurasia continent jointly. Xi Jinping suggested that Norway and China discuss opportunities for cooperation on the Arctic shipping routes and jointly build the PSR. Kirkenes has become a Norwegian focal point for China's PSR plans, as it belongs to Norway and therefore the EEA. Besides, the Finnish President Sauli Niinisto added that Finland is willing to play a decisive role to align this initiative with the EU to promote connectivity of the Eurasian continent better.

Beijing promotes an 'Arctic Corridor' railway project (China Daily 2018), which would link the PSR with the Baltic Sea and continental Europe. The Eurasian BRI would be closed with the missing railway route between Rovaniemi in Finland and Kirkenes in Norway. The costs for this project are estimated to be three billion euros. ${ }^{12}$ From Helsinki in the South of Finland, a multi-billion US\$ tunnel and railway project underneath the Baltic Sea could connect Estonia's capital Tallinn and would mark the end station of the PSR. More than 10,000 Estonians commute to Helsinki every day to take the ferry across the Baltic Sea, a trip that takes $2 \mathrm{~h}$ across the $80 \mathrm{~km}$. The EU has approved $€ 3.1$ million in funding for feasibility studies. The Helsinki-Tallinn connection is also part of the EU's TEN-T network's North SeaBaltic corridor. The governments of Finland and Estonia published a feasibility study that said the tunnel could open in 2040. Chinese actors expressed interest in that tunnel project.

However, considerable doubts remain. The Estonian European Commissioner Director-General for Mobility and Transport Henrik Hololeui questioned the tunnels' necessity, and also Estonia's public administration minister Jaak Aab opined the project was unrealistic (Kentish 2019). Besides, also indigenous people and

\footnotetext{
11 Belt and Road Portal, Full text of China-EU summit joint statement, April 9 2019, https://eng.yidai yilu.gov.cn/zchj/sbwj/85336.htm (accessed May 20 2020).

12 https://arcticcorridor.fi/
} 
environmentalists expressed concerns over the economic and environmental sustainability of Kirkenes-Helsinki railway project.

The EU Commission tries to understand those and other concerns better. In 2019, the EU and Sweden invited for an EU-Arctic Forum in Umeå in the North of Sweden, which also signalled the EU's geopolitical shift towards the Barents sub-Arctic region. The EU's Arctic ambassador Cosinxcs expressed on that occasion that for the future, connectivity issues, climate change adaptation, and geo-economic, but also geopolitical issues will become essential topics of the EU's Arctic policy. Shipping might soon be conducted 9 to 10 months along the NSR through the year. In this phase, the EU remodelled its Arctic approach from a top-down to a bottom-up experiment: instead of commanding a policy from Brussels on the Arctic region, the EU has started to conduct so-called stakeholder dialogues with the local population in the Euro-Arctic. It will be interesting to observe for the years to come, whether and how this approach influences the EU-China infrastructural plans and contribute to rationalize and soften the proclaimed system rivalry.

\section{Conclusion}

The EU and China could ignore each other for years in the Arctic because they possessed no functional role vis-à-vis each other. The Arctic region has also not been a priority for cooperation but has become a place for both to be present and project influence. China's growing Arctic interests found symmetric support by the EuroArctic for years, but not by the EU.

After the first critical juncture, the relations between the EU and China on the Arctic were mostly indirect. Iceland decided against an EU Membership, but for an FTA with China. There was a hectic episode concerning Greenland's mineral resources that at that time attracted Chinese actors, but which remained an episode due to the decline of the prices of the raw materials. However, it marked the begin of the Arctic's globalization and the EU's awareness of China's Arctic rise. While the Euro-Arctic rejected the EU-style regulatory approach, China could socialize better with the lose Arctic regulatory structure than the EU, who wanted to revise it. The EU learned to give up Brussel-style top-down regulatory plans to better socialize with the Arctic.

After the second critical juncture, energy and shipping projects put bilateral Russia-China relations upfront. That also marked a geopolitical shift of China's Arctic priorities towards Russia and Siberian resources. Two coincidences enabled that development. Firstly, the global relaxation of the mineral markets (which decreased external interests in Greenland). Secondly, the Ukrainian crisis and Western sanctions led Russia no other option than to switch towards a very welcoming attitude concerning China's Arctic interests and investments along the NSR.

However, in the third phase, China's BRI and PSR infrastructure goals enforced an orientation of China towards the Barents. Norway and Finland are indispensable for the ports, railway, and tunnel projects. The relations between Norway and China strongly improved, and Norway was the first country to visit by a Chinese delegation during the COVID-19 pandemic in August 2020. Both countries currently negotiate 
on a FTA. Since the EU also aspires to increase its presence in the Barents to raise its Arctic profile in general, this means a synergistic position concerning connectivity and infrastructure. In that sub-Arctic region, China might increase its presence without US interference, which is an additional advantage for China.

Several reasons led the EU more substantial look to the Barents Arctic sub-region in recent years: Russia's military activities in the Baltic and Barents region (Riddervold and Cross 2019); the lower raw material prices that decreased the continental European industries interests in Greenland; economic potentials in the Barents, including raw materials in Northern Scandinavia (Eliasson et al. 2017); the shrinking importance of the Arctic Council and its continued rejection of EU observer status; the EU's existing institutional involvement and impact in the Barents region; the favourable attitude of Sweden and Finland on the EU's involvement on Arctic issues compared to EU-sceptical Denmark; and last but not least, China's PSR ambitions with Norway and Finland as points of intersection. There are plenty of opportunities to tap for China-EU cooperation in that region; however, environmental and social concerns might suggest caution and a compassionate approach. Ironically, the Euro-Arctic states now might promote an EU-regulatory approach on infrastructure investments, including the concerns of indigenous people. That, in turn, could raise the acceptance of China's BRI-ambitions with the EU and the Euro-Arctic.

Abbreviations AC: Arctic Council; BEAC: Barents Euro-Arctic Council; BRI: Belt and Road Initiative; CAP: China's Arctic policy; CNOOC: China National Offshore Oil Corporation; COSCO: China Ocean Shipping Company; CREC: China Railway Engineering Company; EPSC: European Political Strategy Center; EU: European Union; FMPRC: Foreign Ministry of the People's Republic of China; IMO: International Maritime Organisation; ND: Northern Dimension; NSR: Northern Sea Routh; PSR: Polar Silk Road; UNCLOS: United Nations Convention on the Law of the Sea; USGS: United States Geological Survey

Author contribution I am the single author.

Data availability The data is freely available (see references).

Code availability Not applicable.

Declarations

Ethics approval and consent to participate Not applicable.

Adherence to national and international regulations Not applicable.

Consent for publication Not applicable.

Competing interests The authors declare no competing interests. 


\section{References}

Alexeeva OV, Lasserre F (2012) The Snow Dragon: China's strategies in the Arctic. China perspectives, No. $2012 / 3$

Arctic Ocean Conference (2008) 2008 Ilulissat Declaration. Ilulissat, Greenland. https://arcticportal.org/ images/stories/pdf/Ilulissat-declaration.pdf Accessed Nov 202019

Arctic Portal (2020) International Agreements, https://arcticportal.org/arctic-governance/internationalagreements Accessed Jan 252020

Barents Observer (2019) Helsinki-Tallinn tunnel set to be linked with Chinese construction company, July 19 2019, https://thebarentsobserver.com/en/industry-and-energy/2019/07/helsinki-tallinn-tunnel-deal-set-be-inked-chinese-construction-company Accessed Feb 172020

Belt and Road News (2019) Joint communique of the leaders https://www.beltandroad.news/2019/04/28/ joint-communique-of-the-leaders/ Accessed Jan 302020

Biedermann R (2019) Adapting to the changing Arctic? The European Union, the Nordics, and the Barents Governance Mosaic. J Contemp Eur Stud. https://doi.org/10.1080/14782804.2019.1693352

Blunden M (2012) Geopolitics and the Northern Sea Route. Int Aff 88(1):115-129

Brady AM (2017) China as a Polar Great Power. Cambridge University Press, Cambridge

Calder KE (2019) Super continent. The Logic of Eurasian Integration, Stanford University Press, Stanford, p 344

Checkel J (2014) Mechanisms, process, and the study of international institutions. In Bennett A, Checkel J (Eds), Process pracing: From metaphor to analytic tool (strategies for social inquiry). Cambridge University Press, Cambridge, pp. 74-97. https://doi.org/10.1017/CBO9781139 858472.006

China Daily (2018) Mcneicein A, Finland touts 'Arctic Corridor' tunnel, February 32018 http://www. chinadaily.com.cn/a/201803/02/WS5a984a41a3106e7dcc13efe8.html Accessed Feb 152020

Christiansen T, Kirchner E, Wissenbach U (2019) The European Union and China. Red Global Press, London

Coninsx MA (2019) Guest Editorial. The European Union: a key and reliable partner in the Arctic and beyond. Eur Foreign Aff Rev 24(3):237-241

Council of the European Union (2009) Conclusions on Arctic issues, 16828/08, Brussels

Council of the European Union (2014) Council conclusions on developing a European Union Policy towards the Arctic Region Foreign Affairs Council Meeting Brussels, May 2014

Council of the European Union (2016) Council conclusions on the Arctic, Foreign Affairs Council, June 202016

Dodds K (2010) A Polar Mediterranean? Accessibility, resources and sovereignty in the Arctic Ocean. Glob Policy 1(3):301-311

Eliasson K, Ulfarsson GF, Valsson T, Gardarsson SM (2017) Identification of development areas in a warming arctic with respect to natural resources, transportation, protected areas, and geography. Futures 85:14-29. https://doi.org/10.1016/j.futures.2016.11.005

EPSC Strategic Notes (2019) Walking on thin ice: a balanced Arctic strategy for the EU. Issue 31 July 2019

European Commission (2008a) The European Union and the Arctic Region. COM 763 Brussels

European Commission (2008b) The raw materials initiative - meeting our critical needs for growth and jobs in Europe COM 699 Brussels

European Commission (2011) Tackling the challenges in commodity markets and on raw materials. COM 25 Brussels

European Commission (2012a) Developing a European Union Policy towards the Arctic Region: progress since 2008 and next step. JOIN (2012) 19 final Brussels

European Commission (2012b) Joint Press Communique $-15^{\text {th }}$ EU-China Summit: towards a stronger EU-China comprehensive strategic partnership MEMO/12/693 Brussels, September 20

European Commission (2012c) EU trade policy for raw materials second activity report. Brussels: Directorate-General for Trade

European Commission (2016) An integrated European Union policy for the Arctic, April 272016 , JOIN(2016) final

European Commission (2017) Summary report of the Arctic stakeholder forum consultation to identify key investment priorities in the Arctic and ways to better streamline future EU funding programmes for the region. Luxembourg: Publications Office of the European Union 
European Commission (2019) EU-China - a strategic outlook, March 122019

European Maritime Safety Agency (2019) Ballast Water. http://www.emsa.europa.eu/implementationtasks/environment/ballast-water.html Accessed Oct 102019

Finland (2013) Finland's strategy for the Arctic Region 2013. Government Resolution on August 23 2013

Finland's Strategy for the Arctic Region (2010) Prime Minister's Office Publications, 8

Flyvbjerg B (2006) Five misunderstandings about case-study research. Qualitative Inquiry 12(2):219-245

Foreign Ministry of the People's Republic of China (FMPRC) (2014) China's policy paper on the EU: deepen the China-EU comprehensive partnership for mutual benefit and win-win cooperation, April 2014

Foreign Ministry of the People's Republic of China (FMPRC) (2018) China's Arctic Policy, January 262018

Gayazova O (2013) China's rights in the marine Arctic. Int J Mar Coast Law 28(1):61-95

Havnes H (2019) The increasing security focus in China's Arctic policy. The Arctic Institute https:// www.thearcticinstitute.org/increasing-security-focus-china-arctic-policy/ July 2018 (accessed Nov 25 2020)

Hedström P (2008) Studying mechanisms to strengthen causal inferences in quantitative research. The Oxford Handbook of Political Methodology. https://doi.org/10.1093/oxfordhb/9780199286546. 003.0013

Hellstroem J (2014) China's political priorities in the Nordic countries. Ministry of Defense, Stockholm

Humpert M (2019) Chinese shipping company COSCO to send record number of ships through Arctic. High North News, June 12, https://www.highnorthnews.com/en/chinese-shipping-company-coscosend-record-number-ships-through-arctic Accessed Aug 32019

Jakobsen L, Peng J (2012) China's Arctic aspirations. SIPRI Policy Paper, 34, November

Jakobson L (2010) China prepares for an ice-free Arctic. SIPRI Insights on Peace and Security, March, No. $2010 / 2$

Kentish P (2019) The Tallinn-Helsinki tunnel: Europe's boldest project since years. Emerging Europe, November 16 2019, https://emerging-europe.com/intelligence/tunnel-vision/ (accessed Feb 15 2020)

Kingdom of Denmark (2010) Strategy for the Arctic 2011-2010

Kobza P (2015) Civilian Power Europe in the Arctic. How far can the European Union go North?, EU Diplomacy Paper, College of Europe, Brugge, No. 1

Lasserre HLF, Alexeeva O (2014) Is China's interest for the Arctic driven by Arctic shipping potential? Asian Geogr 32(1):59-71

Lunde L, Yang J, Stensdal I (2016) Asian countries and the Arctic future. World Scientific, Singapore

Nordregio (2017) Nordic arctic strategies in overview. Nordregio Policy Brief 2017:1

Northern Dimension (2019) NDPTL regional network and its extension toward Asia, March 182019 http://www.ndptl.org/activities-and-news/-/view/1346 (accessed Feb 8 2020)

Norway (2006) The Norwegian government's high north strategy. https://www.regjeringen.no/globalasse ts/upload/ud/vedlegg/strategien.pdf. Accessed 21 Mar 2021

Norway (2017) Norway's Arctic Strategy — between geopolitics and social development, Norwegian Ministries

Pérez EC, Yaneva VZ (2016) The European Arctic Policy in Progress. Polar Sci 10:441-449. https://doi. org/10.1016/j.polar.2016.06.008

Politico (2019) Pompeo aims to counter China's ambitions in the Arctic, May 6 2019, https://www.polit ico.eu/article/mike-pompeo-counter-china-arctic-ambitions/ (accessed Nov 25 2020)

PAME (2020) Arctic shipping status report. March 312020 https://www.pame.is/projects/arctic-marineshipping/arctic-shipping-status-reports/723-arctic-shipping-report-1-the-increase-in-arctic-shipp ing-2013-2019-pdf-version/file. Accessed 8 Dec 2020

Raspotnik A, Østhagen A (2019) What about the Arctic? The European Union's quest for northern space. Geopolitics. https://doi.org/10.1080/14650045.2019.1670643

Reuters (2012) Greenland's minerals loom in China-Denmark ties, June 16

Reuters (2019), Three Chinese companies to build Tallinn-Helsinki tunnel, July 12 2019, https://www. reuters.com/article/us-finland-estonia-tunnel/three-chinese-companies-to-build-tallinn-helsinki-tunnel-idUSKCN1U70F3 Accessed Feb 152020

Riddervold M, Cross MK (2019) Reactive power EU: Russian aggression and the development of an EU Arctic policy. Eur For Aff Rev 24(1):43-66 
Stępien A, Koivurova T (2017) Arctic Europe: bringing together the EU Arctic policy and Nordic cooperation. Government's Analysis, Assessment and Research, Prime Minister's Office, Finland

Sørensen CTN (2018) China as an arctic great power. Potential implications for greenland and the danish realm, policy brief, royal danish defence college, February 2018, p 6

Sweden (2011) Sweden's strategy for the Arctic Region 2011. Ministry for Foreign Affairs.

Tang G (2013) Arctic issues and China's stance. China Institute of International Studies. March 42013

Tonami A (2016) Asian foreign policy in a changing Arctic. The Diplomacy of Economy and Science at New Frontiers, Palgrave Macmillan

Vennesson P (2008) Case study and process tracing: theories and practices, in Donatella DELLA PORTA and Michael Keating (eds), Approaches and methodologies in the social sciences. a pluralist perspective. Cambridge University Press, Cambridge, 223-239

Wang J, Song W (2016) China, the European Union and the International Politics of Global Governance. Palgrave Macmillan, London

Wegge N (2011) The political order in the Arctic: power structures, regimes and influence. Polar Rec 47(2):165-176

Young O (2019) Is it time for a reset in arctic governance? Sustainability, 11/4497, MDPI. https://www. file://C:/Users/TKUST 1/AppData/Local/Temp/sustainability-11-04497.pdf. Accessed 22 March 2021

Yu L, Sui S (2020) China-Russia military cooperation in the context of the Sino-Russian strategic partnership. Asia Europe Journal 18(3) No.4: 325-345

Publisher's Note Springer Nature remains neutral with regard to jurisdictional claims in published maps and institutional affiliations. 